\title{
Variability in total serum IgE over 1 year in severe asthmatics
}

\author{
Renaud Louis ${ }^{1 *}$, Charles Pilette ${ }^{2}$, Olivier Michel ${ }^{3}$, Alain Michils ${ }^{4}$, Guy Brusselle ${ }^{5}$, Antoine Poskin ${ }^{6}$, \\ Jan Van Schoor ${ }^{6}$, Kris Denhaerynck ${ }^{7,8}$, Stefaan Vancayzeele ${ }^{6}$, Ivo Abraham ${ }^{7}$ and Sandra Gurdain ${ }^{6}$
}

\begin{abstract}
Background: Immunoglobulin E ( $\mathrm{gE} E)$ is the treatment target of omalizumab, a monoclonal antibody indicated in the treatment of severe allergic asthma. Long-term variability of serum total $\left.\lg \mathrm{E}_{(\mathrm{s}} \mathrm{lg}_{\mathrm{tot}}\right)$ in asthmatics remains poorly documented.
\end{abstract}

Methods: In this prospective study, slgE $\mathrm{E}_{\mathrm{tot}}$ levels were measured over 1 year at 7 time points in 41 severe asthmatics treated with high-dose of inhaled corticosteroids and long-acting $\beta_{2}$ agonists. 33 patients were atopic based on at least one positive RAST to common aeroallergens. Patients were divided into three groups according to their baseline slgE $E_{\text {tot }}$ level: low $(<76 \mathrm{IU} / \mathrm{mL} ; n=10)$, intermediate $(76-700 \mathrm{IU} / \mathrm{mL} ; n=20)$ or high $(>700 \mathrm{IU} / \mathrm{mL} ; \mathrm{n}=11)$. Patients also completed the six-item Juniper Asthma Control Questionnaire $\left(\mathrm{ACQ}_{6}\right)$. The $\mathrm{slg} \mathrm{E}_{\mathrm{tot}}$ variability and factors predictive for this variability were studied, as well as $\mathrm{ACQ}_{6}$ outcomes.

Results: The variation in $\mathrm{slg}_{\text {tot }}$ level was mostly the consequence of between patient-variability, which represented $96 \%, 71 \%$ and $96 \%$ of the total variability in the low, intermediate and high slg $\mathrm{E}_{\text {tot }}$ subgroups, respectively. The residual within-patient variability was therefore limited. In 10/41 patients, slg $\mathrm{E}_{\mathrm{tot}}$ levels increased or decreased, for at least one visit, beyond the predefined range of the subgroups to which they were assigned $(<76 \mathrm{IU} / \mathrm{mL} ; 76-700 \mathrm{IU} /$ $\mathrm{mL} ;>700 \mathrm{IU} / \mathrm{mL}$ ). There was a significant but weak correlation between slgE $\mathrm{E}_{\text {tot }}$ and $\mathrm{ACQ}_{6}$ score over all time points $(r=0.15, p=0.02)$, but slg $E_{\text {tot }}$ failed to associate with severe exacerbation. $s l g E_{\text {tot }}$ decreased by $3 \%$ with any additional year of age for the whole group ( $p=0.01)$ and increased by $5 \%$ per one unit of allergen exposure score in atopic patients $(p=0.002)$.

Conclusion: In severe asthmatics, limited within-patient variability of slg $\mathrm{E}_{\text {tot }}$ levels was observed over 1 year as opposed to marked between-subject variability. $\mathrm{slg}_{\text {tot }}$ decreases with age. Variation in slg $\mathrm{E}_{\text {tot }}$ weakly associates with asthma control but not with exacerbation.

Keywords: Asthma, IgE, Variability

\section{Introduction}

Immunoglobulin $\mathrm{E}$ (IgE) is an antibody associated with hypersensitivity and allergic reactions. IgE mainly binds on the high-affinity IgE receptor (FceRI) on mast cells and basophils. Upon FceRI cross-linking following allergen exposure, inflammatory mediators including histamine, leukotrienes and pro-inflammatory cytokines are released [1]. However, in murine models, the binding

\footnotetext{
*Correspondence: R.Louis@chuliege.be

1 Service de Pneumologie-Allergologie, CHU Sart Tilman B35, 4000 Liege, Belgium

Full list of author information is available at the end of the article
}

of IgE itself on mast cell surface may already favour cell survival and cytokine release irrespective of the presence of any allergen $[2,3]$. Although direct evidence for this is still lacking in humans, it has been reported that asthmatics with high sputum IgE levels have also raised sputum levels of TNF $\alpha$ and Interleukin-6, two cytokines released from mast cells [4]. Therefore, IgE might possibly be considered as an inflammatory mediator independent of atopic status and deserves to be monitored.

In a study of a community population with measurements at two time points over an 8-year period, the level of serum total $\operatorname{IgE}\left(\mathrm{sIgE}_{\text {tot }}\right)$ tended to be stable in 
subjects above the age of 35 years while levels decreased in children and young adults. Atopic subjects tended to show a decrease with age even after the age of 35 years [5]. Further, a longitudinal study spanning a period of up to 20 years also showed that smoking opposed the natural decline in IgE and synergized with atopy to result in increased levels in subjects over the age of 50 years [6]. However, variation in $\operatorname{sIgE}_{\text {tot }}$ beyond two or three time points in the same subject has not been studied extensively.

Omalizumab, a monoclonal antibody that binds serum IgE, has become part of asthma treatment for the severe spectrum of the disease in which patients remain uncontrolled despite a combination of high dose inhaled corticosteroids (ICS) with long-acting $\beta_{2}$ agonist (LABA). The drug has been validated in asthmatics whose serum IgE ranges from 30 to $700 \mathrm{IU} / \mathrm{mL}$ but most of the effect in terms of reduction of exacerbation was confined to patients with serum IgE ranging from 76 to $700 \mathrm{IU} / \mathrm{mL}$ [7]. A retrospective chart review of severe asthmatics with two to four measurements of $\mathrm{sIgE}_{\mathrm{tot}}$ over an average period of 2 years showed some clinically significant variability in $\operatorname{sigE} E_{\text {tot }}$ affecting candidacy and dosing of omalizumab [8]. A recent prospective study conducted with 17 moderate-to-severe asthma patients with 6 serial measurements confirmed this variability in $\operatorname{sIgE}_{\text {tot }}$ over 1 year [9].

To better understand $\operatorname{sIgE}_{\text {tot }}$ variation and factors influencing this variation, we conducted a 12-month prospective study of $\operatorname{sIgE}_{\text {tot }}$ levels in severe asthmatics treated with high-dose ICS and LABA. Furthermore, we also examined how fluctuation in IgE may relate to day-to-day environmental exposure, asthma control and exacerbations.

\section{Methods}

\section{Patient characteristics}

Patients enrolled in the study had an established diagnosis of severe asthma as defined by the ERS/ATS consensus statement [10], aged $\geq 18$ years, and currently treated with high-dose ICS (daily dose of fluticasone propionate $>500 \mu \mathrm{g}$ or equivalent) and a LABA. Patients were excluded from the study if: (i) they were being or had been treated with omalizumab (Xolair ${ }^{\circledR}$, Novartis, Basel, Switzerland), unless treatment was stopped at least 1 year before inclusion; (ii) they were undergoing immunotherapy; and/or (iii) used an investigational drug at the time of enrollment or within 30 days prior to enrollment in the study.

\section{Study design}

This was a prospective, multicenter study to assess variability of $s I g E_{\text {tot }}$ levels in severe asthmatics conducted in 5 Belgian centers. The 12-month variability in $\operatorname{sIgE}_{\text {tot }}$ levels in the total population was assessed and the proportion of the total variability explained by withinand between-patient variability was calculated (primary objective). In accordance with reimbursement criteria in Belgium, patients were stratified post hoc into three groups on the basis of baseline $\mathrm{sIgE}_{\text {tot }}:<76 \mathrm{IU} / \mathrm{mL}$ (low IgE), 76-700 IU/mL (intermediate IgE), and $>700 \mathrm{IU} /$ $\mathrm{mL}$ (high IgE). These three groups were selected based on the study of Bousquet et al., which demonstrated that omalizumab reduces the annualized rate of asthma exacerbations more in patients with $\operatorname{sIgE}_{\text {tot }} \geq 76 \mathrm{IU} / \mathrm{mL}$ [7]; and based on the upper limit of serum IgE inclusion criteria of the INNOVATE registration study $(<700 \mathrm{IU} /$ $\mathrm{mL}$ ) [11]. These two studies are currently used as the basis for the reimbursement of omalizumab in Belgium. An additional objective of the study was to evaluate demographic, environmental, and treatment factors that may influence $\operatorname{sIg} \mathrm{E}_{\text {tot }}$ variation and whether $\operatorname{sIg} \mathrm{E}_{\text {tot }}$ relates to asthma control and asthma exacerbation.

At baseline patients completed the six-item Juniper Asthma Control Questionnaire $\left(\mathrm{ACQ}_{6}\right)$ [12]; blood was sampled to measure $\operatorname{sIgE}_{\text {tot }}$ levels; and atopic status of the patient was evaluated with a radio allergosorbent test (RAST) directed towards common allergens: grass mix, birch, mould mix, house dust mite (Dermatophagoides pteronyssinus), and cat and dog dander. Patients were considered atopic if RAST levels to any allergen exceeded $0.35 \mathrm{kU} / \mathrm{L}$. Additionally, an environmental questionnaire was completed which enquired about the frequency of patients' exposure (1: "once, more than 1 month ago"; 2 : "once, more than 1 week ago"; 3 : "once, within the last week"; 4: "occasionally"; 5: "frequently" or 6: "constantly") to house dusts, pollens, molds, cats and dogs, smoke, humidifier/vaporizer, and carpeting.

Subsequently, 6 visits were planned every 2 months for a follow-up period of 12 months. At each visit, $\operatorname{sgE} E_{\text {tot }}$ was measured, the $\mathrm{ACQ}_{6}$ and environmental questionnaires were completed, and the treatment prescribed by the physician was registered. Treatment prescription, continuation, or discontinuation was per the physician's best clinical judgment and in accordance with the Belgian reimbursement criteria. Also, to allow for the monitoring of exacerbations during the study, patients had to report if and how many times they had an exacerbation since the last visit. The presence of an exacerbation in the week preceding the visit was recorded specifically. A severe exacerbation was defined as an exacerbation requiring a treatment containing systemic corticosteroids for at least three consecutive days and/or an emergency room visit and/or a hospitalization.

This study was approved by the ethical committee of the CHU Liege under approval number B70720096731. 
All patients had to provide an informed consent before entering the study.

\section{Statistical analysis}

Descriptive statistics were calculated using frequencies, percentages, means, standard deviations, medians and ranges as appropriate. Comparisons in baseline characteristics between the three subgroups (low, intermediate, high $\operatorname{sIg} \mathrm{E}_{\text {tot }}$ ) were tested using ANOVA with Tukey post hoc test comparison for age and a general linear model with contrasts for other (categorical) variables. Random-intercepts regression analysis was used to model $\log$-transformed $\operatorname{sg} \mathrm{E}_{\text {tot }}$, with 'patient' as the random variable. The model allowed us to calculate intra-cluster correlations to determine how much of the variability observed in $\operatorname{sIgE}_{\text {tot }}$ levels over time could be attributed to variability between individual patients, compared to variability within each patient. It also allowed us to test predictors of $\operatorname{sIgE}_{\text {tot }}$ (exposure to allergens, active/passive exposure to tobacco smoke, change in asthma treatment, treatment with maintenance systemic corticosteroids, and $\mathrm{ACQ}_{6}$ score). Modeling of exacerbations (absent/present) was performed by logistic regression analysis, using generalized estimating equations to account for repeated measurements over time. This analysis was used to assess influence of treatment changes and time of year. The correlation between $\operatorname{sIgE}_{\text {tot }}$ and $\mathrm{ACQ}_{6}$ score at baseline was evaluated with a Spearman correlation. As this was a real-life study, data were collected from routine clinical practice and there may be missing data. Missing values were not imputed in the descriptive and statistical analyses. $p$ values $<0.05$ were considered statistically significant.

\section{Results}

\section{Patient characteristics}

In total, 41 patients were recruited. The median $\operatorname{sig} \mathrm{E}_{\text {tot }}$ level at baseline in the entire study group was $248 \mathrm{IU} /$ $\mathrm{mL}$ (range $17-7620 \mathrm{IU} / \mathrm{mL}$ ). Mean $\mathrm{ACQ}_{6}$ score was $1.5 \pm 0.87$. Only $14 / 39$ patients $(35 \% ; 2$ responses unknown) had asthma GINA-defined as controlled at baseline. Of these 41 patients, 10 (27\%) were included in the low $\operatorname{sIgE}_{\text {tot }}$ subgroup $(\leq 76 \mathrm{IU} / \mathrm{mL}$; median baseline $\mathrm{sIgE}_{\mathrm{tot}}=43.5 \mathrm{IU} / \mathrm{mL}$, range $\left.17-71 \mathrm{IU} / \mathrm{mL}\right) ; 20$ patients $(49 \%)$ were included in the intermediate $\operatorname{sIgE}_{\text {tot }}$ subgroup (76-700 IU $/ \mathrm{mL}$; median baseline $\mathrm{sIgE}_{\text {tot }}$ level $=247.0 \mathrm{IU} /$ $\mathrm{mL}$ (range $86-667 \mathrm{IU} / \mathrm{mL}$ ); and 11 patients $(24 \%)$ were included in the high $\operatorname{sIgE}_{\text {tot }}$ subgroup $(>700 \mathrm{IU} / \mathrm{mL}$; median baseline $\operatorname{sIgE}_{\text {tot }}$ level $=1332.0 \mathrm{IU} / \mathrm{mL}$, range $729-7620 \mathrm{IU} / \mathrm{mL}$ ). Atopy, defined as a positive RAST to at least one common aeroallergen, was present in 33/41 subjects (80\%). The baseline characteristics by subgroup are given in Table 1.

\section{Variability in slgE $\mathrm{E}_{\text {tot }}$ over 12 months}

The between-patient variability represented $93.4 \%$ of the total variability for the entire sample, and $96 \%$, $71 \%$ and $96 \%$ in the low, intermediate, and high $\operatorname{sig} E_{\text {tot }}$ subgroups, respectively. Therefore, within-patient variability represented $4 \%, 29 \%$ and $4 \%$ of the total variability in the low, intermediate and high $\operatorname{sigE} E_{\text {tot }}$ subgroups, respectively. The within-patient variability was significantly higher in the intermediate $\mathrm{sIgE}_{\text {tot }}$ group than in the other groups $(\mathrm{p}<0.0001)$ (Table 2).

Detailed individual trajectories over time by baseline IgE strata are shown in Fig. 1, panels a, c, and d. Ten of the 41 patients (24\%) reached values beyond the limit of their own baseline $\operatorname{sIgE}_{\text {tot }}$ subgroup during at least one of the follow-up visits. Of these 10 patients, 4 were in the low, 4 in the intermediate, and 2 in the high $\operatorname{sg} E_{\text {tot }}$ subgroup, therefore representing $40 \%$ of the patients in the low $\operatorname{sg} E_{\text {tot }}$ subgroup, $20 \%$ of the patients in the intermediate $\operatorname{sIg} \mathrm{E}_{\text {tot }}$ subgroup and $18 \%$ of the patients in the high $\operatorname{sIgE}_{\text {tot }}$, respectively.

Two patients had sIgE $\mathrm{E}_{\text {tot }}$ levels in the three categories over the 1 year period of observation. One patient initially in the low sIgE group had a rise in IgE above $700 \mathrm{IU} / \mathrm{mL}$ for at least 2 consecutive measurements before returning to intermediate levels at the two last visits (Fig. 1b). This patient was subsequently found to have developed a parasitic infection.

The relevant clinical data for this patient are presented in Table 3. The patient did not have any positive RAST results at baseline and was therefore considered non-atopic.

\section{Relationship between variation in slgE $\mathrm{E}_{\text {tot }}$ and demographics, environmental exposure and treatment features}

Age was a significant predictor of $\operatorname{sig} \mathrm{E}_{\text {tot }}$ levels over 12 months. $\operatorname{sig} E_{\text {tot }}$ decreased by $3 \%$ with each additional year of age $(p=0.01)$. Allergen exposure for patients with a history of a positive RAST test was associated with change in $\operatorname{sIgE}_{\text {tot }}$. Exposure scores ranged from 0 to 12 and reflected the sum of the frequencies of exposure for the different allergens for which the patient had shown a positive RAST. A unit increase in the exposure score was associated with a $5 \%$ rise $\operatorname{sIgE}_{\text {tot }}(\mathrm{p}=0.002)$. No relationship was found between $\operatorname{sig} \mathrm{E}_{\text {tot }}$ and gender, smoke exposure, and asthma treatment.

\section{Relationship between slg $\mathrm{E}_{\text {tot }}$ and lung function, asthma control, and exacerbation}

There was no relationship between lung function (\% predicted FEV1) and $\operatorname{sIgE}_{\text {tot }}$ variation at baseline or throughout the study period. The odds of severe asthma 
Table 1 Baseline characteristics stratified by slgEtot group (low, intermediate, high)

\begin{tabular}{|c|c|c|c|c|c|}
\hline Baseline characteristics ( $N=41$ ) & $\begin{array}{l}\text { Low IgE group } \\
(<76 \mathrm{IU} / \mathrm{mL}) \\
(\mathrm{N}=10)\end{array}$ & $\begin{array}{l}\text { Intermediate lgE group } \\
(76-700 \mathrm{IU} / \mathrm{mL})(\mathrm{N}=20)\end{array}$ & $\begin{array}{l}\text { High IgE group } \\
(>700 \mathrm{IU} / \mathrm{mL}) \\
(\mathrm{N}=11)\end{array}$ & $p$ value ${ }^{* *}$ & Difference specification ${ }^{* * *}$ \\
\hline \multicolumn{6}{|l|}{ Age (years) } \\
\hline Mean $( \pm S D)$ & $57.7 \pm 15.7$ & $49.5 \pm 14.7$ & $40.4 \pm 13.4$ & $0.03^{*}$ & 1 vs 3 \\
\hline \multicolumn{6}{|l|}{ Gender } \\
\hline Male & $5(29 \%)$ & $8(47 \%)$ & $4(24 \%)$ & 0.84 & \\
\hline Female & $5(21 \%)$ & $12(50 \%)$ & $7(29 \%)$ & & \\
\hline \multicolumn{6}{|l|}{ Race } \\
\hline Caucasian & $10(28 \%)$ & $19(53 \%)$ & $7(19 \%)$ & $0.03^{*}$ & 1 vs $3 ; 2$ vs 3 \\
\hline Other & $0(0 \%)$ & $1(20 \%)$ & $4(80 \%)$ & & \\
\hline \multicolumn{6}{|l|}{ Smoking status } \\
\hline Never smoked & $6(26 \%)$ & $12(52 \%)$ & $5(22 \%)$ & 0.27 & \\
\hline Former smoker & $3(25 \%)$ & $7(58 \%)$ & $2(17 \%)$ & & \\
\hline Current smoker & $1(17 \%)$ & $1(17 \%)$ & $4(66 \%)$ & & \\
\hline \multicolumn{6}{|l|}{ BMI $\left(\mathrm{kg} / \mathrm{m}^{2}\right)$} \\
\hline$<30$ & $9(25 \%)$ & $17(47 \%)$ & $10(28 \%)$ & 0.79 & \\
\hline$\geq 30$ & $1(25 \%)$ & $3(75 \%)$ & $0(0 \%)$ & & \\
\hline \multicolumn{6}{|l|}{ Medical history } \\
\hline Allergic rhinitis & $2(9 \%)$ & $13(56 \%)$ & $8(35 \%)$ & $0.02^{*}$ & 1 vs $3 ; 1$ vs 2 \\
\hline Atopic dermatitis & $3(17 \%)$ & $11(61 \%)$ & $4(22 \%)$ & 0.33 & \\
\hline GERD & $4(44 \%)$ & $4(44 \%)$ & $1(11 \%)$ & 0.23 & \\
\hline Nasal polyps & $2(25 \%)$ & $3(38 \%)$ & $3(38 \%)$ & 0.59 & \\
\hline \multicolumn{6}{|l|}{ Residence } \\
\hline City & $4(18 \%)$ & $10(45 \%)$ & $8(36 \%)$ & 0.51 & \\
\hline Suburbs & $4(40 \%)$ & $5(50 \%)$ & $1(10 \%)$ & & \\
\hline Rural/country & $2(22 \%)$ & $5(56 \%)$ & $2(22 \%)$ & & \\
\hline \multicolumn{6}{|l|}{ GINA level of asthma control } \\
\hline Controlled & $3(21 \%)$ & $8(57 \%)$ & $3(21 \%)$ & 0.39 & \\
\hline Partly controlled & $2(18 \%)$ & $7(64 \%)$ & $2(18 \%)$ & & \\
\hline Uncontrolled & $5(33 \%)$ & $4(27 \%)$ & $6(40 \%)$ & & \\
\hline \multicolumn{6}{|l|}{ Positive RAST testing } \\
\hline D. pteronyssinus & $4(18 \%)$ & $11(50 \%)$ & $7(32 \%)$ & 0.65 & \\
\hline Grass mix & $4(22 \%)$ & $6(33 \%)$ & $8(44 \%)$ & 0.07 & 2 vs 3 \\
\hline Cat dander & $2(12 \%)$ & $10(59 \%)$ & $5(29 \%)$ & 0.41 & \\
\hline Dog dander & $2(12 \%)$ & $7(44 \%)$ & $7(44 \%)$ & 0.16 & \\
\hline Birch & $0(0 \%)$ & $5(42 \%)$ & $7(58 \%)$ & $0.005^{*}$ & 1 vs $3 ; 2$ vs $3 ; 2$ vs 3 \\
\hline Mold & $1(8 \%)$ & $5(42 \%)$ & $6(50 \%)$ & 0.1 & \\
\hline \multicolumn{6}{|l|}{ Treatment } \\
\hline $\mathrm{ICS} / \mathrm{LABA}$ & $10(24 \%)$ & 20 (49\%) & $11(27 \%)$ & - & \\
\hline SABA & $5(18 \%)$ & $18(64 \%)$ & $5(18 \%)$ & $0.02^{*}$ & 1 vs $2 ; 2$ vs 3 \\
\hline LTRA & $2(10 \%)$ & $12(60 \%)$ & $6(30 \%)$ & 0.11 & \\
\hline oCs & $1(13 \%)$ & $3(37 \%)$ & $4(50 \%)$ & 0.34 & \\
\hline SABA/SAAC & $1(33 \%)$ & $1(33 \%)$ & $1(33 \%)$ & 1 & \\
\hline LABA & $0(0 \%)$ & $1(100 \%)$ & $0(0 \%)$ & 1 & \\
\hline \multicolumn{6}{|l|}{ Asthma status } \\
\hline \% Predicted FEV1—mean (SD) & $72.3 \pm 28.6$ & $86.6 \pm 18.6$ & $80.2 \pm 12.2$ & 0.20 & \\
\hline ACQ total score-median (range) & $12.0(2.0-14.0)$ & $8.0(5.0-13.0)$ & $8.0(4.0-13.0)$ & 0.77 & \\
\hline Exhaled nitric oxide-median (range) & $15.6(7.1-46.7)$ & $20.8(9.6-154.0)$ & $120.9(5.7-236.0)$ & 0.82 & \\
\hline
\end{tabular}

BMI, Body Mass Index; D. pteronyssinus, Dermatophagoides pteronyssinus; FEV1, forced expiratory volume in $1 \mathrm{~s}$; GERD, gastroesophageal reflux disease; ICS, inhaled corticosteroids; ICS/LABA, inhaled corticosteroids/long-acting $\beta_{2}$ agonists; LABA, long-acting $\beta_{2}$ agonists; LTRA, leukotriene receptor antagonist; OCS, oral corticosteroids; RAST, radio-allergo sorbent test; SD, standard deviation; SABA, short-acting $\beta_{2}$ agonists; SABA/SAAC, short-acting anticholinergic

${ }^{*} \mathrm{p}$-value $<0.05$ were considered statistically significant; ${ }^{* *}$ Regression analysis for age/Fisher's exact for other (categorical) variables; ${ }^{* * *}$ Tukey test for age/general linear model with contrasts for other (categorical) variables, the column indicates between which groups were observed the statistical differences: $1=$ low slg $\mathrm{E}_{\text {tot }}$ subgroup, 2 =intermediate $\operatorname{slg} \mathrm{E}_{\text {tot }}$ subgroup and $3=$ high slg $\mathrm{E}_{\text {tot }}$ subgroup 
exacerbations the year prior to enrollment were not correlated significantly with baseline $\operatorname{sIgE}_{\text {tot }}$ in the total study group $(\mathrm{OR}=0.95 ; \mathrm{p}=0.21)$, nor in the low $(\mathrm{OR}=0.85 ; \mathrm{p}=0.95)$, intermediate $(\mathrm{OR}=0.82 ; \mathrm{p}=0.42)$ or high subgroup $(\mathrm{OR}=0.96 ; \mathrm{p}=0.31)$. Over the entire study period, there was no correlation between $\operatorname{sIg} E_{\text {tot }}$ and severe exacerbations since the previous visit nor with

Table 2 Intra-cluster correlation (ICC) of serum total $\lg E\left(s \mid g E_{\text {tot }}\right)$ evaluated over the 12-month study period in three strata of asthmatic patients based on $\operatorname{sig} E_{\text {tot }}$ at baseline: $<76 \mathrm{IU} / \mathrm{mL}(\mathrm{n}=10) ; 76-700 \mathrm{IU} / \mathrm{mL} \quad(n=20)$ and $>700 \mathrm{IU} / \mathrm{mL}(\mathrm{n}=11)$

\begin{tabular}{llcl}
\hline & ICC (95\% Cl) $\left(^{*}\right)$ & 1-ICC (95\% Cl) & p-value $\left(^{* *}\right)$ \\
\hline$<76 \mathrm{IU} / \mathrm{mL}$ & $96(93-98) \%$ & $4(2-7) \%$ & \\
$76-700 \mathrm{IU} / \mathrm{mL}$ & $71(62-82) \%$ & $29(18-38) \%$ & $<0.0001$ \\
$>700 \mathrm{IU} / \mathrm{mL}$ & $96(94-99) \%$ & $4(1-6) \%$ & \\
\hline
\end{tabular}

$\mathrm{Cl}$, confidence interval

* Between-patient variability/(between- + within-patient variability) ${ }^{* *}$ likelihood ratio test comparing within-patient variabilities exacerbation that occurred the week before the visits. At baseline there was no relationship between sIgE and $\mathrm{ACQ}_{6}$ in the whole group (Spearman's $\rho=0.01, \mathrm{p}=0.96$ ) nor in any of the three groups. There was a significant but weak correlation between $\operatorname{sIgE}_{\text {tot }}$ and $\mathrm{ACQ}_{6}$ score across all time points $(\mathrm{r}=0.15, \mathrm{p}=0.02)$.

\section{Influence of seasons on slg $\mathrm{E}_{\text {tot }}$ asthma control}

Figure 2 shows the variation in $\operatorname{sIgE}_{\text {tot }}$ (panel a) and asthma control (panel b) according to the seasons. In the total study group, there was no association between seasons (March-May, June-August; SeptemberNovember; December-February) and $\operatorname{sIgE}_{\text {tot }}(\mathrm{p}=0.47)$ or $\mathrm{ACQ}_{6}$ score $(\mathrm{p}=0.43)$.

\section{Discussion}

There are limited data in the literature on the stability of IgE measurements over time in asthmatics. In the current study, we investigated variations in $\operatorname{sIgE}_{\text {tot }}$ in severe asthmatics over a 1 year period with repeated measurements every 2 months. The principal finding is

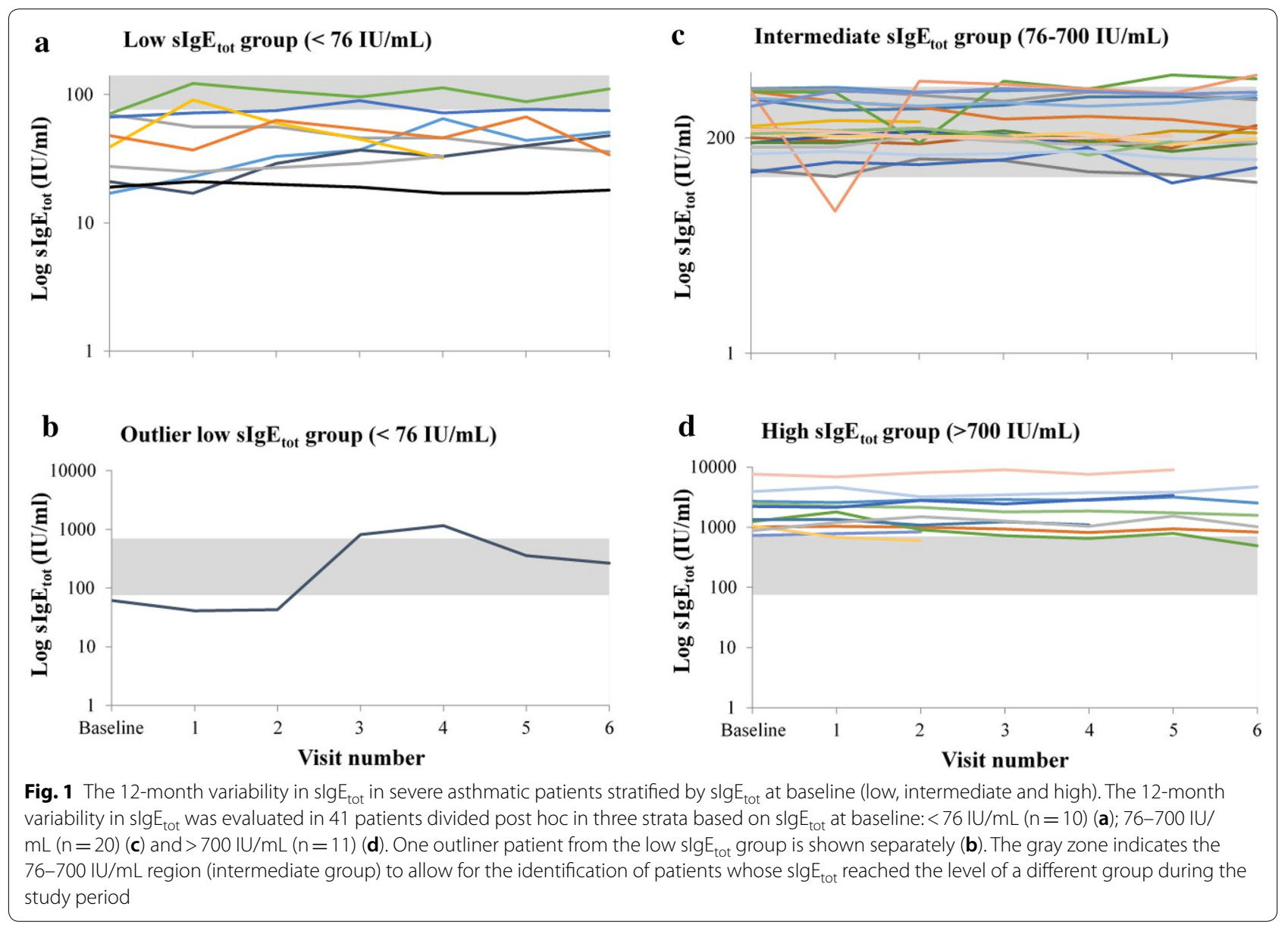


Table 3 Clinical data for the outliner patient belonging to the low serum total IgE (slgEtot) subgroup (see Fig. 1b)

\begin{tabular}{|c|c|c|c|c|c|c|c|}
\hline Visit & Baseline & 1 & 2 & 3 & 4 & 5 & 6 \\
\hline slgE $\mathrm{t}_{\text {tot }}(\mathrm{IU} / \mathrm{mL})$ & 61.3 & 41 & 43 & 818 & 1159 & 357 & 266 \\
\hline FEV1 predicted (\%) & 49 & & 61 & 64 & 52 & 59 & 65 \\
\hline Total ACQ score & 13 & 19 & 14 & 25 & 19 & 15 & 16 \\
\hline FENO (ppm) & 7.1 & & 4.8 & 18.6 & & & 28.1 \\
\hline Asthma exacerbation & $x$ & $x$ & $x$ & x & $x$ & & \\
\hline $\begin{array}{l}\text { Asthma exacerbation requiring OCS (if } \\
\text { yes dosis } \mathrm{mg} \text { ) }\end{array}$ & & & & 32 & 16 & & \\
\hline Parasitic infection & & & & $x$ & & & \\
\hline Budesonide/formoterol ( $\mu \mathrm{g} /$ days) & $1200 / 54$ & $1200 / 54$ & $800 / 36$ & $1200 / 54$ & $1200 / 54$ & $1200 / 54$ & $1200 / 54$ \\
\hline OCS dosis (mg/days) & 16 & 16 & 8 & 16 & 16 & 16 & 16 \\
\hline Beclamethasone/formoterol & & $200 / 18$ & $200 / 18$ & & & $200 / 18$ & $200 / 18$ \\
\hline Salbutamol & $x$ & & & $x$ & $x$ & & \\
\hline Fenoterol/ipratropium & & & $x$ & & & & \\
\hline Theophylline & $x$ & & $x$ & $x$ & & $x$ & $x$ \\
\hline Azythromycine & $x$ & $x$ & $x$ & & & & \\
\hline
\end{tabular}

FEV $_{1}$, forced expiratory volume in $1 \mathrm{~s}$; FENO, fractional exhaled nitric oxide; OCS, oral corticosteroids

that most of the variability $\operatorname{sg} \mathrm{E}_{\text {tot }}$ was due to betweenpatient variability whereas within-patient variability of $\mathrm{sIgE}_{\text {tot }}$ levels was rather limited. $\mathrm{sIgE}_{\text {tot }}$ was found to decrease with age.

The relative stability in $\operatorname{sIgE}_{\text {tot }}$ suggests that the mechanisms regulating IgE levels are sustained over time in most patients. Nonetheless, $24 \%$ of patients showed $\operatorname{sIgE}_{\text {tot }}$ level scores beyond the range of their own group for at least one visit. This was particularly the case in patients with baseline $\operatorname{sIgE}_{\text {tot }}<76 \mathrm{IU} / \mathrm{mL}$ as 4 out of 10 patients had a measurement above $76 \mathrm{IU} / \mathrm{mL}$ in at least one subsequent blood sample.

Omalizumab is a biologic with proven efficacy to improve asthma quality of life and reduce asthma exacerbations in severe allergic asthmatics. The findings from our study suggest that regular monitoring of $\operatorname{sIg} \mathrm{E}_{\text {tot }}$ in routine clinical practice may assist in optimizing treatment by aligning it with observed variations in $\operatorname{sIgE} \mathrm{E}_{\text {tot }}$ and thus avoid under-treatment with omalizumab. As the $40 \%$ of patients with $\operatorname{sIgE}_{\text {tot }}<76 \mathrm{IU} / \mathrm{mL}$ at baseline but subsequent serum levels in the $76-700 \mathrm{IU} / \mathrm{mL}$ range underscore, without repeated blood sampling these patients might not have been initiated on omalizumab, which may have translated into a subsequent preventable need for corticosteroid therapy or into preventable exacerbations and hospitalizations. Likewise, the 20\% of patients with $\operatorname{sIgE}_{\text {tot }}$ between 700 and $1000 \mathrm{IU} /$ $\mathrm{mL}$ who subsequently showed serum levels below the $700 \mathrm{IU} / \mathrm{mL}$ threshold might not have been initiated on omalizumab without repeated testing. However, patients with very high serum IgE levels $(>2000 \mathrm{IU} / \mathrm{mL}$ ) remain fairly stable in this "high" zone. Although betweenpatient variability was the major trend identified in our study, limited within-patient variability was still present. Therefore, regular monitoring of SIgE over 1 year results in an increase from 50 to $66 \%$ of patients falling into the range between 76 and $700 \mathrm{IU} / \mathrm{mL}$. The limited patient variability resulted in the fact that two-third (27/41) of our patients treated with high doses ICS/LABA had a serum IgE values between 76 and $700 \mathrm{IU} / \mathrm{mL}$ after a 1 year period of observation (including 7 measurements for most of them), a figure clearly higher than $50 \%$ of patients as observed at baseline.

Despite the limited within-patient variability, one patient with baseline $\operatorname{sIgE}_{\text {tot }}<76 \mathrm{IU} / \mathrm{mL}$ showed significant changes in serum levels over the observation period. This patient who was non-atopic, maintained low IgE levels $(<76 \mathrm{IU} / \mathrm{mL})$ at the first two visits, after which there was a marked increase to $818 \mathrm{IU} / \mathrm{mL}$ at the third and $1159 \mathrm{IU} / \mathrm{mL}$ at the fourth visit, before declining at subsequent visits without, however, returning to low serum levels. This patient was a severe corticosteroiddependent asthmatic in whom a parasitic infection was detected and treated accordingly. Remarkably, when the $\operatorname{sgg} \mathrm{E}_{\text {tot }}$ increased sharply at visit 3 , the patient's $\mathrm{ACQ}_{6}$ scores rose from 2.3 to 4.2 without any change in $\mathrm{FEV}_{1}$ but with an augmentation of the OCS dose as treatment adjustment. This case points at the importance of considering possible etiologies when a sharp rise in IgE is detected. IgE levels are known to increase in the case of parasitic infection, namely helminth infections [13]; yet other causes of elevated IgE outside an atopic status should also be considered including infections by mycobacterium tuberculosis, Epstein-Barr virus, cytomegalovirus, malignancies, or chronic inflammatory/ dysimmune disorders [14]. 

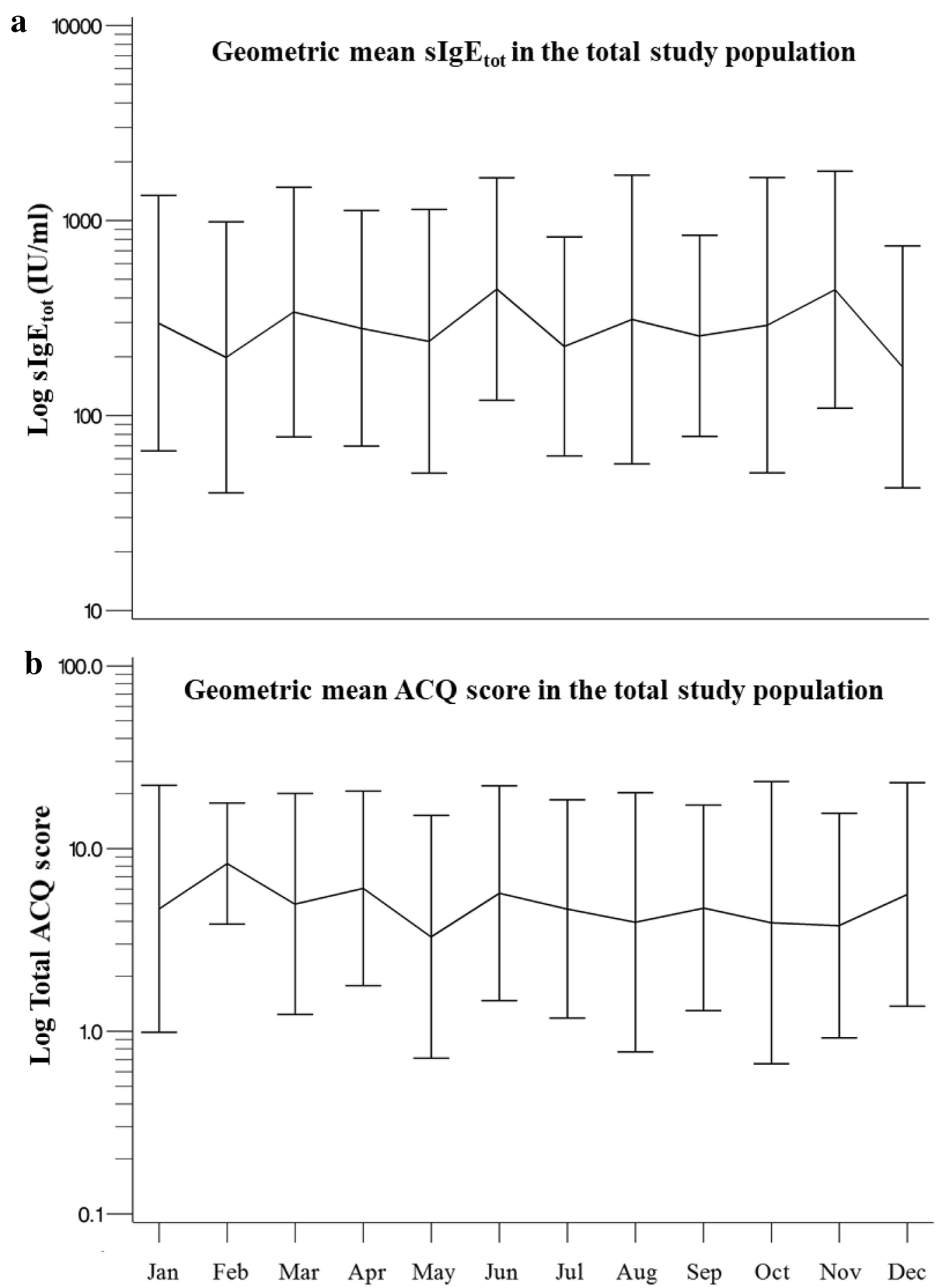

Fig. 2 Variation in slg $\mathrm{E}_{\text {tot }}$ and asthma control in severe asthmatic patients $(n=41)$ according to the seasons. Data from the 6 follow-up visits are shown according to the month of the visit (the baseline data are not included). In these graphics, the geometric mean slg $\mathrm{E}_{\text {tot }}$ with standard deviation (SD) (a) and the geometric mean six-item Juniper Asthma Control Questionnaire (ACQ $)$ score with SD (b) are given

Though not powered for that purpose, our study also showed an inverse relationship between age and serum IgE, a finding we have recently reported in a large cross-sectional study in asthmatics [15] and which was previously established in longitudinal population studies $[5,6]$. A decrease in $\operatorname{sIgE}_{\text {tot }}$ by $3 \%$ with every year 
increase in age was observed in the present study. Not unexpectedly, allergen exposure score was associated with a rise of $\operatorname{sIgE}_{\text {tot }}$ in sensitized subjects, supporting a role for allergen exposure in IgE synthesis in addition to its role in mast cell activation thereby confirming a recent study [9].

In contrast to what is known for eosinophils [16, 17], there are limited data on the relationship between $\operatorname{sIgE}_{\text {tot }}$ and asthma control and severity. A higher $\operatorname{sIgE} E_{\text {tot }}$ level in severe asthmatics as compared to that in mild to moderate asthmatics has recently been reported in a large real-life cross-sectional study even if there was a considerable overlap between the groups [15]. In the same study, there was however no correlation between $\mathrm{ACQ}_{7}$ and serum IgE. In the study reported here, though not present at baseline, a weak but significant correlation was observed between $\operatorname{sIgE} E_{\text {tot }}$ and $\mathrm{ACQ}_{6}$ score throughout the study period, which suggests that fluctuation in IgE over time in a subject may relate to day-to-day asthma symptoms. By contrast, no relationship was found between $\operatorname{sIgE} E_{\text {tot }}$ and severe exacerbation rates. Recent data from SARP (Severe Asthma Research Program) have shown an inverse and surprising relationship between serum IgE and propensity to severe exacerbation in asthmatics [18].

Omalizumab convincingly reduces asthma exacerbation in clinical trial and routine practice in patients with serum IgE ranging from 30 to $700 \mathrm{IU} /$ $\mathrm{mL}$. The efficacy of omalizumab was shown when free circulating IgE was reduced by more than $95 \%$ and maintained at lower than $30 \mathrm{IU} / \mathrm{mL}$ [19]; however, $\operatorname{sIgE}_{\text {tot }}$ itself prior to treatment initiation does not predict the ability of the drug to prevent exacerbation [20]. Rather than considering the baseline IgE level, the IgE level at which omalizumab is able to maintain free circulating IgE may be more relevant in terms of reduction in exacerbations. It is also likely that airway (and not serum) IgE, which can be assessed in sputum $[4,21]$ and bronchial biopsies [22, 23], plays a more important role in the disease than circulating IgE though a convincing correlation was reported between serum and sputum IgE levels [4]. We might have found a stronger relationship between IgE and exacerbation if we had measured airway IgE rather than serum IgE in the present study.

The main limitation of our study is the limited number of patients included and followed up throughout the protocol. This may have resulted in a lack of association between sIgE and seasons in contrast to what was reported by others [9]. Moreover, we did not found a relationship between smoke exposure and serum IgE. Our negative finding does not preclude, however, any real effect of smoke exposure on serum IgE because of the limited number of current smoking asthmatics in our cohort. Future studies with larger sample sizes are needed to confirm our findings and explore associations with other possible determinants of IgE variation. Asthmatics in this study were selected on the basis of disease severity defined by the requirement of high-dose ICS combined with a LABA. Therefore, the IgE variability depicted here may not be applicable to a population of mild untreated asthmatics. As we did not have detailed history data regarding atopic dermatitis we could not assess the influence of the disease evolution on $\operatorname{sig} E_{\text {tot }}$ over the study period; specifically, whether change in atopic dermatitis severity may have influenced change in serum IgE in our study. In our study the majority of patients with atopic dermatitis were in the intermediate IgE group.

We conclude that in severe asthmatics receiving highdose ICS combined with a LABA, there was limited within-patient variability of $\operatorname{sIgE}_{\text {tot }}$ but significant between-patient variability. Yet $30 \%$ of the patients not initially eligible for receiving omalizumab based on a single measurement may actually benefit from repeated measurements to qualify for treatment.

\section{Abbreviations \\ ACQ: Asthma Control Questionnaire; $\mathrm{ACQ}_{6}$ : six-item Juniper Asthma Control Questionnaire; BMI: Body Mass Index; D. pteronyssinus: Dermatophagoides pteronyssinus; FceRl: high-affinity IgE receptor; $F_{E V}$ : forced expiratory volume in $1 \mathrm{~s}$; FENO: fractional exhaled nitric oxide; GERD: gastroesophageal reflux disease; ICC: intra-cluster correlation; ICS: inhaled corticosteroids; ICS/LABA: inhaled corticosteroids/long-acting $\beta_{2}$ agonists; IgE: immunoglobulin $E$; LABA: long-acting $\beta_{2}$ agonist; LTRA: leukotriene receptor antagonist; OCS: oral corticosteroids; OR: odds ratio; RAST: radio-allergo sorbent test; SABA: short-acting $\beta_{2}$ agonists; SABA/SAAC: short-acting $\beta_{2}$ agonists/short-acting anticholinergic; SARP: Severe Asthma Research Program; SD: standard deviation; slgE $_{\text {tot }}$ : serum total lgE.}

\section{Authors' contributions}

SG and SV designed the study. IA and KD wrote the protocol and performed the analyzes. JVS reviewed the protocol. GB, RL, AM, OM and CP collected the data. IA, KD, SG, RL, CP and AP interpreted the data. RL and AP wrote the manuscript. All authors read and approved the final manuscript.

\section{Author details \\ 1 Service de Pneumologie-Allergologie, CHU Sart Tilman B35, 4000 Liege, Belgium. ${ }^{2}$ Cliniques Universitaires Saint-Luc, Avenue Hippocrate 10, 1200 Brussels, Belgium. ${ }^{3}$ CHU Brugmann, Place A.Van Gehuchten 4, 1020 Brussels, Belgium. ${ }^{4}$ CUB Hôpital Erasme, Route de Lennik 808, 1070 Brussels, Belgium. ${ }^{5}$ UZ Gent, Corneel Heymanslaan 10, 9000 Ghent, Belgium. ${ }^{6}$ Novartis Pharma, Medialaan 40, 1800 Vilvoorde, Belgium. ${ }^{7}$ Matrix45, LLC, 6159 West Sunset Road, Tucson, AZ 85743, USA. ${ }^{8}$ University of Basel, Basel, Switzerland.}

\section{Competing interests}

$\mathrm{GB}, \mathrm{RL}, \mathrm{AM}, \mathrm{OM}$ and $\mathrm{CP}$ are members of an Advisory Board of Novartis Pharma, Belgium.

IA and KD work for Matrix45, LLC. By company policy employees are prohibited from owning equity in or perform services independently for sponsor organizations. Matrix45 provides similar services to other biopharmaceutical on a non-exclusivity basis.

SG, AP, JVS and SV are employees of Novartis Pharma, Belgium. 


\section{Availability of data and materials}

The datasets generated and analyzed during the current study are not publicly available but are available from the corresponding author on reasonable request.

\section{Consent for publication}

Not applicable.

\section{Ethics approval and consent to participate}

This study was approved by the ethical committee of the CHU Liege under Approval Number B70720096731. All patients had to provide an informed consent before entering the study.

\section{Funding}

This study was funded by Novartis Pharma, Belgium.

\section{Publisher's Note}

Springer Nature remains neutral with regard to jurisdictional claims in published maps and institutional affiliations.

Received: 5 June 2018 Accepted: 4 March 2019

Published online: 29 March 2019

\section{References}

1. Gould HJ, Sutton BJ, Beavil AJ, Beavil RL, McCloskey N, Coker HA, Fear D, Smurthwaite L. The biology of IGE and the basis of allergic disease. Annu Rev Immunol. 2003;21:579-628.

2. Asai K, Kitaura J, Kawakami Y, Yamagata N, Tsai M, Carbone DP, Liu FT, Galli SJ, Kawakami T. Regulation of mast cell survival by IgE. Immunity. 2001;14:791-800.

3. Kalesnikoff J, Huber M, Lam V, Damen JE, Zhang J, Siraganian RP, Krystal G. Monomeric IgE stimulates signaling pathways in mast cells that lead to cytokine production and cell survival. Immunity. 2001;14:801-11.

4. Manise M, Holtappels G, Van CK, Schleich F, Bachert C, Louis R. Sputum IgE and cytokines in asthma: relationship with sputum cellular profile. PLoS ONE. 2013:8:e58388.

5. Barbee RA, Halonen M, Kaltenborn W, Lebowitz M, Burrows B. A longitudinal study of serum $\mathrm{lgE}$ in a community cohort: correlations with age, sex, smoking, and atopic status. J Allergy Clin Immunol. 1987:79:919-27.

6. Sherrill DL, Halonen M, Burrows B. Relationships between total serum IgE, atopy, and smoking: a twenty-year follow-up analysis. J Allergy Clin Immunol. 1994;94:954-62.

7. Bousquet J, Rabe K, Humbert M, Chung KF, Berger W, Fox H, Ayre G, Chen $\mathrm{H}$, Thomas K, Blogg M, Holgate S. Predicting and evaluating response to omalizumab in patients with severe allergic asthma. Respir Med. 2007;101:1483-92.

8. Mummadi SR, Hatipoglu US, Gupta M, Bossard MK, Xu M, Lang D. Clinically significant variability of serum IgE concentrations in patients with severe asthma. J Asthma. 2012;49:115-20.

9. Hatipoglu U, Subramanian A, Campbell T, Rice R, Mummadi S, Hu B, Lang DM. Intrasubject variability in total IgE levels in patients with moderate to severe persistent allergic asthma over 1 year. J Allergy Clin Immunol Pract. 2016;4:691-6

10. Chung KF, Wenzel SE, Brozek JL, Bush A, Castro M, Sterk PJ, Adcock IM, Bateman ED, Bel EH, Bleecker ER, Boulet LP, Brightling C, Chanez P, Dahlen SE, Djukanovic R, Frey U, Gaga M, Gibson P, Hamid Q, Jajour NN, Mauad T, Sorkness RL, Teague WG. International ERS/ATS guidelines on definition, evaluation and treatment of severe asthma. Eur Respir J. 2014;43:343-73.

11. Humbert M, Beasley R, Ayres J, Slavin R, Hebert J, Bousquet J, Beeh KM, Ramos S, Canonica GW, Hedgecock S, Fox H, Blogg M, Surrey K. Benefits of omalizumab as add-on therapy in patients with severe persistent asthma who are inadequately controlled despite best available therapy (GINA 2002 step 4 treatment): INNOVATE. Allergy. 2005;60:309-16.
12. Juniper EF, Svensson K, Mork AC, Stahl E. Measurement properties and interpretation of three shortened versions of the Asthma Control Questionnaire. Respir Med. 2005;99:553-8.

13. Capron M, Capron A. Immunoglobulin E and effector cells in schistosomiasis. Science. 1994;264:1876-7.

14. Pien GC, Orange JS. Evaluation and clinical interpretation of hypergammaglobulinemia E: differentiating atopy from immunodeficiency. Ann Allergy Asthma Immunol. 2008;100:392-5.

15. Manise M, Bakayoko B, Schleich F, Corhay JL, Louis R. IgE mediated sensitisation to aeroallergens in an asthmatic cohort: relationship with inflammatory phenotypes and disease severity. Int J Clin Pract. 2016;70:596-605.

16. Demarche SF, Schleich FN, Paulus VA, Henket MA, Van Hees TJ, Louis RE. Asthma control and sputum eosinophils: a longitudinal study in daily practice. J Allergy Clin Immunol Pract. 2017;5:1335-43.

17. Schleich FN, Chevremont A, Paulus V, Henket M, Manise M, Seidel L, Louis R. Importance of concomitant local and systemic eosinophilia in uncontrolled asthma. Eur Respir J. 2014;44(1):97-108. https://doi. org/10.1183/09031936.00201813

18. Denlinger LC, Phillips BR, Ramratnam S, Ross K, Bhakta NR, Cardet JC, Castro M, Peters SP, Phipatanakul W, Aujla S, Bacharier LB, Bleecker ER, Comhair SA, Coverstone A, DeBoer M, Erzurum SC, Fain SB, Fajt M, Fitzpatrick AM, Gaffin J, Gaston B, Hastie AT, Hawkins GA, Holguin F, Irani AM, Israel E, Levy BD, Ly N, Meyers DA, Moore WC, Myers R, Opina MT, Peters MC, Schiebler ML, Sorkness RL, Teague WG, Wenzel SE, Woodruff PG, Mauger DT, Fahy JV, Jarjour NN. Inflammatory and comorbid features of patients with severe asthma and frequent exacerbations. Am J Respir Crit Care Med. 2017;195:302-13.

19. Chapman KR, Cartier A, Hebert J, Mclvor RA, Schellenberg RR. The role of omalizumab in the treatment of severe allergic asthma. Can Respir J. 2006;13(Suppl B):1B-9B.

20. Hanania NA, Wenzel S, Rosen K, Hsieh HJ, Mosesova S, Choy DF, Lal P, Arron JR, Harris JM, Busse W. Exploring the effects of omalizumab in allergic asthma: an analysis of biomarkers in the EXTRA study. Am J Respir Crit Care Med. 2013;187:804-11.

21. Mouthuy J, Detry B, Sohy C, Pirson F, Pilette C. Presence in sputum of functional dust mite-specific IgE antibodies in intrinsic asthma. Am J Respir Crit Care Med. 2011;184:206-14.

22. Takhar P, Corrigan CJ, Smurthwaite L, O'Connor BJ, Durham SR, Lee TH, Gould HJ. Class switch recombination to lgE in the bronchial mucosa of atopic and nonatopic patients with asthma. J Allergy Clin Immunol. 2007;119:213-8.

23. Ying S, Humbert M, Meng Q, Pfister R, Menz G, Gould HJ, Kay AB, Durham SR. Local expression of epsilon germline gene transcripts and RNA for the epsilon heavy chain of $\mathrm{lg} E$ in the bronchial mucosa in atopic and nonatopic asthma. J Allergy Clin Immunol. 2001;107:686-92.

Ready to submit your research? Choose BMC and benefit from:

- fast, convenient online submission

- thorough peer review by experienced researchers in your field

- rapid publication on acceptance

- support for research data, including large and complex data types

- gold Open Access which fosters wider collaboration and increased citations

- maximum visibility for your research: over 100M website views per year

At BMC, research is always in progress.

Learn more biomedcentral.com/submissions 